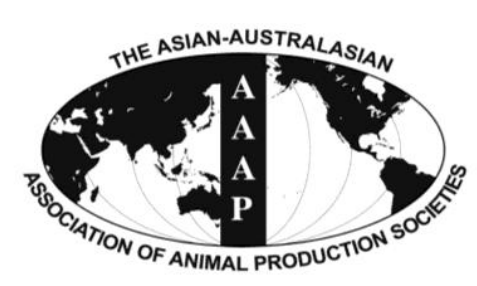

\title{
Nitrogen Metabolism in Lactating Goats Fed with Diets Containing Different Protein Sources
}

\author{
A. B. Santos*, M. L. A. Pereira, H. G. O. Silva, M. S. Pedreira, G. G. P. Carvalho ${ }^{1}$, \\ L. S. O. Ribeiro, P. J. P. Almeida, T. C. J. Pereira, and J. V. Moreira \\ Southwest State University of Bahia, Itapetinga - Bahia, 45700-000, Brazil
}

\begin{abstract}
This study aimed to evaluate urea excretion, nitrogen balance and microbial protein synthesis in lactating goats fed with diets containing different protein sources in the concentrate (soybean meal, cottonseed meal, aerial part of cassava hay and leucaena hay). Four Alpine goats whose mean body weight was $42.6 \pm 6.1 \mathrm{~kg}$ at the beginning of the experiment, a mean lactation period of $94.0 \pm 9.0$ days and a production of $1.7 \pm 0.4 \mathrm{~kg}$ of milk were distributed in a $4 \times 4$ Latin square with four periods of 15 days. Diets were formulated to be isonitrogenous, containing $103.0 \mathrm{~g} / \mathrm{kg}$ of $\mathrm{CP}, 400 \mathrm{~g} / \mathrm{kg}$ of Tifton 85 hay and $600 \mathrm{~g} / \mathrm{kg}$ of concentrate. Diet containing cottonseed meal provided $(\mathrm{p}<0.05)$ increased excretion of urea and urea nitrogen in the urine $(\mathrm{g} / \mathrm{d}$ and $\mathrm{mg} / \mathrm{kg}$ of $\mathrm{BW})$ when compared with leucaena hay. The diets affected the concentrations of urea nitrogen in plasma $(\mathrm{p}<0.05)$ and excretion of urea nitrogen in milk, being that soybean meal and cottonseed meal showed $(\mathrm{p}<0.05)$ higher than the average aerial part of the cassava hay. The use of diets with cottonseed meal as protein source in the concentrate in feeding of lactating goats provides greater nitrogen excretion in urine and negative nitrogen balance, while the concentrate with leucaena hay as a source of protein, provides greater ruminal microbial protein synthesis. (Key Words: Microbial Protein Synthesis, Nitrogen Balance, Purine Derivatives, Urea Nitrogen)
\end{abstract}

\section{INTRODUCTION}

Feeding of lactating goats raised under intensive system is responsible for most of the production costs. Generally the Protein supplements are of vegetable origin such the soybean meal that present high price and contribute to increase to feed cost (Mendes et al., 2010). Several factors contribute to preclude the use of soybean meal in the formulation of diets for ruminants and among these their use in food of humans and monogastric; increasing exports to make biofuels. Addition to being one of the world's leading commodity and its price is determined by negotiations in stock exchanges.

The Northeast region of Brazil presents conditions

\footnotetext{
* Corresponding Author: A. B. Santos. Tel: +55-77-3261-8662, Fax: +55-77-3261-8600, E-mail: alanasantos10@hotmail.com

${ }^{1}$ Federal University of Bahia, Salvador - Bahia, 40170-110, Brazil.

Submitted Jun. 26, 2013; Revised Oct. 28, 2013; Accepted Dec. 29, 2013
}

favorable climate for goat breeding, because of that, has the largest herd when compared with other regions. The northeast is characterized by being a semiarid region with low rainfall, and seasonal forage production. Thus, to maintain continuous production of milk during the year, it is necessary to intensify production systems, showing the need to seek alternative sources of protein that has regional availability, with the aim of reducing production costs.

The leucaena is a leguminous easily found in semiarid regions, has high production, excellent quality and palatability, moreover, and contains protein in their leaves around $29 \%$ of dry matter (DM) (Segundo et al., 2006). Another protein food resource with regional availability is cassava, in which their cultural remains or aerial part can be used for hay production and thus be stored and used as a protein ingredient in diets, especially in periods of shortage of fodder. At harvest cassava is estimated that $80 \%$ of the aerial parts of the plant are discarded (Nunes Irmão et al., 2008)

The increasing number of agricultural industries in

Copyright @ 2014 by Asian-Australasian Journal of Animal Sciences This is an open-access article distributed under the terms of the Creative Commons Attribution Non-Commercial License (http://creativecommons.org/licenses/by-nc/3.0/), which permits unrestricted non-commercial use, distribution, and reproduction in any medium, provided the original work is properly cited. 
northeastern Brazil has generated various types of agroindustrial byproducts that can be used in diets and generally have low acquisition cost, which can reduce the cost with supplement in the feedlots in addition to avoid environmental problems. According Murta et al. (2011), Brazil produces about 130 million tons of residues and these include the biodiesel, such as cottonseed. This coproduct has nutritional characteristics that fits as potential substitute of soybean meal, and presents $38.1 \%$ of crude protein (CP) (Neiva Junior et al., 2007).

The microbial protein synthesis, urea excretion and nitrogen balance are parameters that allow verifying the synchronism between sources of nitrogen and energy and consequently the efficient use of nitrogen in the rumen. In areas where supplements are scarce, the increased flow of microbial nitrogen to the duodenum through a feeding program based on the regionally available concentrated food is an effective and sustainable method of productivity improvement (Argolo et al., 2010).

The study was conducted to evaluate the excretion of urea, nitrogen balance and microbial protein synthesis in lactating goats fed with different sources of protein in concentrate (soybean meal, cottonseed meal, aerial part of cassava hay and leucaena hay).

\section{MATERIAL AND METHODS}

\section{Experimental materials and procedures}

The experiment was conducted at the goat farming unit "Departamento de Tecnologia Rural e Animal" (Rural and Animal Technology Department) - DTRA, of the Southwest State University of Bahia, Itapetinga, BA, Brazil, located $15^{\circ} 09^{\prime} 07^{\prime \prime}$ south latitude, $40^{\circ} 15^{\prime} 32^{\prime \prime}$ west longitude, with average annual rainfall of $800 \mathrm{~mm}$, average annual temperature of $27^{\circ} \mathrm{C}$ and average altitude of $268 \mathrm{~m}$.

Four Alpine goats whose mean live weight was $42.6 \pm 6.1 \mathrm{~kg}$ at the beginning of the experiment, a mean lactation period of $94.0 \pm 9.0$ days and a production of $1.7 \pm 0.4 \mathrm{~kg}$ of milk were confined in individual stalls with cement floor and dimensions of $1.5 \times 2.0 \mathrm{~m}$. The animals were divided in a $4 \times 4$ Latin square with four periods of 15 days, of which ten were for adaptation and five for sample collection. The goats were fed diets with different protein sources in concentrate: soybean meal, cottonseed meal, aerial part of cassava hay and leucaena hay. The diets were isonitrogenous, contained $103.0 \mathrm{~g} / \mathrm{kg}$ of the $\mathrm{CP}$ with based in DM consisted of Tifton 85 hay $(400 \mathrm{~g} / \mathrm{kg})$ and concentrates $(600 \mathrm{~g} / \mathrm{kg})$ and were balanced according to the NRC (2007) (Table 1).

Diets were available ad libitum, twice daily, at 07:00 and 16:00, and were arranged in a way that orts remained around 50 to $100 \mathrm{~g} / \mathrm{kg}$ of the total food; water was constantly available. During the collection period, from the 10 th to the 15 th day of trial period, samples of forage, concentrates and orts of each animal were daily collected, packed in plastic bags and stored at $-20^{\circ} \mathrm{C}$ for laboratory analysis. In order to estimate the percentage of nitrogen in body weight, the animals were weighed at the beginning and at the end of every trial period.

For the purpose of measuring and evaluating voluntary intake, the supplied food and orts produced between the 10 th and the 15th day of each trial period were considered. The voluntary intake was calculated as the difference between the supplied food and leftovers.

\section{Analysis}

Samples of forages, concentrates and orts of each animal were pre-dried in a forced ventilation incubator, at $60^{\circ} \mathrm{C}$ and ground in a knife mill (1 mm mesh sieve). The contents of DM, ash, CP, ether extract (EE), neutral detergent fiber (NDF), acid detergent fiber (ADF), neutral detergent insoluble protein (NDIP), acid detergent insoluble protein (ADIP), cellulose, hemicellulose and lignin $(72 \%$ w/ $\mathrm{W}_{2} \mathrm{SO}_{4}$ ) were determined following the procedures described by Silva and Queiroz (2002). The content of NDF corrected for ash and protein (NDFap) was obtained according to the recommendations by Licitra et al. (1996) and Mertens (2002).

The non-fibrous carbohydrate, with corrections for ash and protein (NFCap) content, was calculated with an adapted equation of the one proposed by Hall (2003):

$$
\mathrm{NFCap}=100-(\mathrm{CP}+\mathrm{EE}+\mathrm{Ash}+\mathrm{NDFap}))
$$

Where: NFCap = estimated content of non-fibrous carbohydrates $(\mathrm{g} / \mathrm{kg}$ of $\mathrm{DM}) ; \mathrm{CP}=$ content of $\mathrm{CP}(\mathrm{g} / \mathrm{kg}$ of $\mathrm{DM}) ; \mathrm{EE}=\mathrm{EE}$ content $(\mathrm{g} / \mathrm{kg}$ of $\mathrm{DM}) ; \mathrm{NDFap}=\mathrm{NDF}$ content corrected for ash and protein $(\mathrm{g} / \mathrm{kg}$ of $\mathrm{DM})$.

The estimated total digestible nutrients (TDNest) of the raw materials and the total diets were calculated according to the equations described by NRC (2001).

Feces collection of animals was carried out during two alternate days, at different times (at 07:00 and 15:00) between the 12th and 13th day of each period, as described by Ítavo et al. (2002). Feces samples were pre-dried milled in a knife mill with a $1.0 \mathrm{~mm}$ sieve mesh; after that, scheduled compound samples were taken from each animal.

To estimate the fecal excretion was used the indigestible NDF as internal indicator. Samples of the provided food (hay, concentrate), orts and feces were incubated for $240 \mathrm{~h}$ (Casali et al., 2008) in duplicate $\left(20 \mathrm{mg} \mathrm{MS} / \mathrm{cm}^{2}\right)$, in bags of non-woven fabric $\left(100 \mathrm{~g} / \mathrm{m}^{2}\right)$, in the rumen of three fistulated animals. After that period, the remaining material was subjected to incubation with neutral detergent extraction (Mertens, 2002) for quantification the 
Table 1. Feed composition and nutrient content of experimental diets

\begin{tabular}{|c|c|c|c|c|}
\hline \multirow{2}{*}{ Ingredient (g/kg DM) } & \multicolumn{4}{|c|}{ Diet } \\
\hline & Soybean meal $^{1}$ & Cottonseed meal $^{2}$ & Cassava hay ${ }^{3}$ & Leucaena hay $^{4}$ \\
\hline Hay of Tifton 85 & 400.0 & 400.0 & 400.0 & 400.0 \\
\hline Mesquite pod meal & 268.0 & 250.0 & 250.0 & 241.0 \\
\hline Ground corn & 267.0 & 250.0 & 250.0 & 240.0 \\
\hline Soybean meal & 37.0 & - & - & - \\
\hline Cottonseed meal & - & 72.0 & - & - \\
\hline Aerial part of cassava hay & - & - & 74.0 & - \\
\hline Leucaena hay & - & - & - & 90.0 \\
\hline Urea & 5.0 & 5.0 & 5.0 & 5.0 \\
\hline Mineral mixture ${ }^{5}$ & 23.0 & 23.0 & 21.0 & 24.0 \\
\hline Total & 1.000 & 1.000 & 1.000 & 1.000 \\
\hline \multicolumn{5}{|l|}{ Nutrient } \\
\hline Dry matter (g/kg) & 897.7 & 899.3 & 884.6 & 896.2 \\
\hline Organic matter (g/kg DM) & 925.5 & 928.9 & 922.5 & 921.4 \\
\hline Crude protein (g/kg DM) & 99.0 & 103.0 & 105.0 & 103.0 \\
\hline $\operatorname{NDIP}(g / k g ~ C P)$ & 260.4 & 249.7 & 312.8 & 292.4 \\
\hline $\operatorname{ADIP}(\mathrm{g} / \mathrm{kg} \mathrm{CP})$ & 212.4 & 221.1 & 246.6 & 226.1 \\
\hline Rumen degradable protein (g/kg DM) & 21.0 & 29.0 & 21.0 & 22.0 \\
\hline Rumen undegradable protein (g/kg DM) & 78.0 & 74.0 & 84.0 & 81.0 \\
\hline Ether extract (g/kg DM) & 20.6 & 25.8 & 10.0 & 17.7 \\
\hline NDFap (g/kg DM) & 417.9 & 438.8 & 445.4 & 443.8 \\
\hline Acid detergent fiber (g/kg DM) & 258.8 & 278.0 & 293.2 & 285.6 \\
\hline Lignin $(g / k g ~ D M)$ & 31.9 & 37.2 & 52.9 & 48.8 \\
\hline Non-fibrous carbohydrates (g/kg DM) & 387.5 & 361.5 & 362.0 & 357.1 \\
\hline Total digestible nutrients ${ }^{6}$ & 674.1 & 669.1 & 621.3 & 636.6 \\
\hline
\end{tabular}

DM, dry matter; CP, crude protein; NDIP, neutral detergent insoluble protein; ADIP, acid detergent insoluble protein; NDFap, neutral detergent fiber corrected for ash and protein.

${ }^{1}$ Diet containing soybean meal as a protein ingredient. ${ }^{2}$ Diet containing cottonseed meal as a protein ingredient.

${ }^{3}$ Diet containing aerial part cassava hay as a protein ingredient. ${ }^{4}$ Diet containing leucaena hay as a protein ingredient.

${ }^{5} 444.0 \mathrm{~g} / \mathrm{kg}$ dicalcium phosphate, $186.0 \mathrm{~g} / \mathrm{kg}$, common salt, $370.0 \mathrm{~g} / \mathrm{kg}$ commercial mineral salt.

${ }^{6}$ Estimated according to the NRC (2001).

indigestible NDF levels. The fecal excretion values were obtained through the relationship between consumption and fecal concentration of indigestible NDF.

The goats were milked by hand twice a day milking time for exam 09:00 and 16:00 production was recorded. Milk samples were collected in the afternoon of the 11th day and in the morning of the 12th day; part of the overall production $(10 \mathrm{~g} / \mathrm{kg})$ was used for analysis of total nitrogen and urea. Part of the milk was deproteinized with trichloroacetic acid $(10 \mathrm{~mL}$ of milk were mixed with $5 \mathrm{~mL}$ of $250 \mathrm{~g} / \mathrm{kg}$ trichloroacetic acid, filtered using filter paper, stored at $-20^{\circ} \mathrm{C}$ ) and analysis of allantoin was conducted using the filtrate.

On 14th day, approximately $4 \mathrm{~h}$ after the delivery of food in the morning, blood was collected from the jugular vein, using $5 \mathrm{~mL}$ EDTA tubes (Vacutainer). Then, blood samples were transferred to the laboratory, centrifuged at $3.500 \mathrm{rpm}$, for $10 \mathrm{~min}$, and plasma was packed in Ependorff tubes and kept frozen $\left(-20^{\circ} \mathrm{C}\right)$ until the completion of urea analysis.
On the 15th day of each trial period, total collections of urine were conducted; the collections were made using Foley $\mathrm{N}_{\circ} 10$ catheters and lasted $24 \mathrm{~h}$. The total urine was collected in $5 \mathrm{~L}$ plastic gallons containing $100 \mathrm{~mL}$ of $\mathrm{H}_{2} \mathrm{SO}_{4}$ at $200 \mathrm{~g} / \mathrm{kg}$ and, at the end of each collection, it was weighed, homogenized and filtered through cheesecloth and a proportion of $100 \mathrm{~g} / \mathrm{kg}$ of the daily volume was removed. These samples were prepared with $\mathrm{pH}$ below three so as to avoid bacterial destruction of the metabolites present in urine; soon after, the samples were stored at $-20^{\circ} \mathrm{C}$ and used in the quantification of urinary concentrations of urea, total nitrogen, creatinine, allantoin, uric acid, xanthine, and hypoxanthine.

The daily excretion of creatinine (DEC $\mathrm{mg} / \mathrm{kg}$ of $\mathrm{BW}$ ) was obtained as:

$$
\mathrm{DEC}=\frac{\text { creatinine concentration } \times \text { urinary volume }}{\text { body weight }}
$$

Where, creatinine concentration $(\mathrm{mg} / \mathrm{L})$ in urine 
samples (total collection); average urinary volume (L) obtained within $24 \mathrm{~h}$; animal's body weight $(\mathrm{kg})$.

Creatinine and uric acid concentrations in urine and urea in urine and plasma were determined using commercial kits. Multiplying values by a factor of 0.4667 performed conversion of urea nitrogen in urea. The urinary levels of allantoin, xanthine, hypoxanthine and total nitrogen were estimated using colorimetric methods, as specified by Chen and Gomes (1992); the total nitrogen content was estimated using the Kjeldahl method (Silva and Queiroz, 2002).

Nitrogen balance (N-retained, g/d) was calculated by difference between $\mathrm{N}$ intake and excretion of the $\mathrm{N}$ in feces, urine and milk.

The excretion of total purine was estimated by the sum of allantoin in urine and milk, and uric acid, xanthine and hypoxanthine excreted in urine. The amount of microbial purines absorbed (MPA, mmol/d) was estimated from the excretion of total purines (ETP, mmol/d), using the equation proposed by Belenguer et al. (2002) for goats:

$$
\operatorname{MPA}(\mathrm{mmol} / \mathrm{d})=\frac{\operatorname{ETP}(\mathrm{mmol} / \mathrm{d})}{0.76}
$$

Where, the value of 0.76 corresponds to the rate of recovery of purines.

The intestinal flow of microbial nitrogen was estimated from the amount of purines absorbed ( $\mathrm{mmol} / \mathrm{d})$, according to the equation:

$$
\text { Microbial nitrogen }(\mathrm{g} / \mathrm{d})=\frac{\text { Absorbed purines }}{0.92 \times 1.97}
$$

Where Belenguer et al. (2002) have assumed that 0.92 is the true digestibility of purine bases in the duodenum and 1.97 (mmol of purine bases/g nitrogen) is the ratio between purine and nitrogen content in the rumen microbial population extracted from the goats.

The efficiency of microbial protein synthesis was obtained through the relationship of microbial protein synthesis $(\mathrm{g} / \mathrm{d})$ with the consumption of TDN $(\mathrm{kg} / \mathrm{d})$.

\section{Statistical analysis}

Dependent variables were analyzed using the MIXED procedure of SAS (Statistical Analysis System), adopting 0.05 as critical level of probability, of the according to the following model:

$$
\mathrm{Y}_{\mathrm{ijk} \mathrm{l}_{1}}=\mu+\mathrm{LS}_{\mathrm{i}}+\mathrm{D}_{\mathrm{j}}+(\mathrm{P} / \mathrm{LS})_{\mathrm{ik}}+(\mathrm{G} / \mathrm{LS})_{\mathrm{il}}+\varepsilon_{\mathrm{ijk}}
$$

Were, $\mathrm{Y}_{\mathrm{ijkl}}=$ observation in the goat 1 , in to period $\mathrm{k}$, subjected to diet $\mathrm{j}$, in to Latin square $\mathrm{i} ; \mu=$ overall effect of the average; $\mathrm{LS}_{\mathrm{i}}=$ effect of the Latin square $\mathrm{i}$, being $\mathrm{i}=1$;
$D_{j}=$ effect of the diet $\mathrm{j}$, being $\mathrm{j}=1,2,3,4 ;(\mathrm{P} / \mathrm{LS})_{\mathrm{ik}}=$ effect of period $\mathrm{k}$, within the Latin square $\mathrm{i}$, being $\mathrm{k}=1,2,3,4$; $(\mathrm{G} / \mathrm{LS})_{\mathrm{il}}=$ effect of the goat 1 , within the Latin square $\mathrm{i}$, being $1=1,2,3,4 ; \varepsilon_{\mathrm{ijkl}}=$ random error associated with each observation, presupposed NID $\left(0, \sigma^{2}\right)$. To evaluate differences among diets were used contrasts, adopting a significance level of the $\alpha=0.05$.

\section{RESULTS AND DISCUSSION}

The diets containing cottonseed meal $(\mathrm{p}<0.05)$ increased excretion of urea and urea nitrogen in the urine $(\mathrm{g} / \mathrm{d}$ and $\mathrm{mg} / \mathrm{kg}$ of BW) when compared with leucaena hay (Table 2). Possibly, this fact was due to the higher concentration of rumen degradable protein $(29.0 \mathrm{~g} / \mathrm{kg}$ of $\mathrm{DM})$ in the diet with cottonseed meal (Table 1). During rumen fermentation, whenever ammonia concentration exceeds the level of utilization by rumen microorganisms, it is absorbed by the rumen wall and is transported to the liver via enterohepatic circulation. In the liver, ammonia is converted into urea that, along with the urea produced in the liver and followed by the metabolism of amino acids form the greatest part of urinary urea (Carvalho et al., 2010).

Studies assessing the nitrogen metabolism in lactating goats fed with different protein sources are scarce; thus, the results obtained are consistent with the responses observed by Pessoa et al. (2009), who have studied dairy heifers supplemented with wheat meal, soybean meal, cottonseed meal or whole cottonseed and noted that the animals fed with soybean meal and cottonseed meal had higher concentrations of nitrogen excretion and urea in urine.

As this study shows, and also according to a survey conducted by Vasconcelos et al. (2010), a higher excretion of urea has been found for Holstein cows fed with soybean meal, raw soybeans, toasted soybeans and soybean meal $+5 \%$ urea.

The protein sources have affected the concentrations of urea nitrogen in plasma $(\mathrm{p}<0.05)$ and milk, being that the diets containing soybean and cottonseed meal showed $(\mathrm{p}<0.05)$ highest average than aerial part of cassava hay (Table 2). The highest concentration of urea nitrogen in plasma and milk of goats fed with soybean and cottonseed meal can be explained by the increased degradation of dietary protein in the rumen, or perhaps by the lack of synchronization between the skeletons of carbon and nitrogen used by microorganisms during synthesis.

Values of plasma urea nitrogen similar to those found in the present study were reported by Oliveira (2009) that evaluating the substitution of corn for mesquite pod meal at levels of $0.0 ; 33.3 ; 66.7$ and $100 \%$ of natural matter, in diets provided to goats in the beginning of lactation have been analyzed and an average of $13.48 \mathrm{mg} / \mathrm{dL}$ has been observed. It is noteworthy that the diets of both experiments contained 
Table 2. Excretion and concentration of urea and urea nitrogen in urine, milk and plasma in lactating goats fed with diets containing different protein sources in the concentrate

\begin{tabular}{|c|c|c|c|c|c|c|}
\hline \multirow{2}{*}{ Item } & \multicolumn{4}{|c|}{ Protein sources in the diet } & \multirow{2}{*}{ SEM } & \multirow{2}{*}{ p-value } \\
\hline & Soybean meal & Cottonseed meal & Cassava hay & Leucaena hay & & \\
\hline \multicolumn{7}{|l|}{ Concentration (mg/dL) } \\
\hline $\mathrm{N}$-urea plasma & 13.0 & 13.1 & 11.4 & 12.8 & 0.43 & 0.038 \\
\hline $\mathrm{N}$-urea milk & 23.1 & 22.4 & 20.2 & 22.7 & 1.02 & 0.372 \\
\hline \multicolumn{7}{|l|}{ Excretion (g/d) } \\
\hline Urea urine & 15.2 & 15.7 & 13.5 & 12.8 & 1.23 & 0.093 \\
\hline $\mathrm{N}$-urea urine & 7.1 & 7.3 & 6.3 & 6.0 & 0.57 & 0.094 \\
\hline N-urea milk & 3.6 & 3.2 & 2.9 & 3.3 & 0.14 & 0.080 \\
\hline \multicolumn{7}{|l|}{ Excretion (mg/kg BW) } \\
\hline Urea urine & 350.5 & 368.3 & 311.0 & 296.6 & 23.50 & 0.086 \\
\hline \multirow[t]{3}{*}{$\mathrm{N}$-urea urine } & 163.6 & 171.9 & 145.1 & 138.4 & 10.97 & 0.086 \\
\hline & \multicolumn{6}{|c|}{ Analyses of contrasts } \\
\hline & $\mathrm{SM}_{\mathrm{vs}} \mathrm{CM}^{1}$ & $\mathrm{SM}_{\text {vs }} \mathrm{CH}^{2}$ & SM vs $\mathrm{LH}^{3}$ & $\mathrm{CM}$ vs $\mathrm{CH}^{4}$ & $\mathrm{CM}_{\mathrm{vs} \mathrm{LH}^{5}}$ & $\mathrm{CH}$ vs $\mathrm{LH}^{6}$ \\
\hline N-urea plasma (mg/dL) & 0.891 & 0.015 & 0.651 & 0.013 & 0.559 & 0.028 \\
\hline Urea urine $(g / d)$ & 0.662 & 0.165 & 0.055 & 0.081 & 0.031 & 0.574 \\
\hline $\mathrm{N}$-urea urine $(\mathrm{g} / \mathrm{d})$ & 0.664 & 0.167 & 0.066 & 0.083 & 0.032 & 0.574 \\
\hline N-urea milk (g/d) & 0.129 & 0.016 & 0.177 & 0.026 & 0.827 & 0.121 \\
\hline Urea urine (mg/kg BW) & 0.528 & 0.181 & 0.079 & 0.064 & 0.027 & 0.609 \\
\hline N-urea (mg/kg BW) & 0.528 & 0.181 & 0.079 & 0.064 & 0.027 & 0.609 \\
\hline
\end{tabular}

BW, body weight; $\mathrm{N}$, nitrogen; SEM, standard error of mean.

${ }^{1}$ Probability of contrast between soybean meal (SM) and cottonseed meal (CM).

${ }^{2}$ Probability of contrast between soybean meal (SM) and aerial part of cassava hay $(\mathrm{CH})$

${ }^{3}$ Probability of contrast between soybean meal (SM) and leucaena hay (LH).

${ }^{4}$ Probability of contrast between cottonseed meal $(\mathrm{CM})$ and aerial part of cassava hay $(\mathrm{CH})$.

${ }^{5}$ Probability of contrast between cottonseed meal (CM) and leucaena hay (LH).

${ }^{6}$ Probability of contrast between aerial part of cassava hay $(\mathrm{CH})$ and leucaena hay $(\mathrm{LH})$.

similar CP content (103 vs $94 \mathrm{~g} / \mathrm{kg}$ of DM) this fact may explain the observed similarity.

The average concentration of urea nitrogen in milk obtained in this experiment $(22.1 \mathrm{mg} / \mathrm{dL})$ is above the maximum limit established by Jonker et al. (1999), who reported that the concentration of milk urea nitrogen in cattle should range from 10 to $16 \mathrm{mg} / \mathrm{dL}$, given that higher values could indicate excessive consumption of nitrogen or high concentrations of rumen degradable protein. For goats are considered selective feeders that always seek the most nutritious food, it is possible that the concentration of urea nitrogen in the milk of these animals is higher than that of bovine animals, but that does not indicate loss of nitrogen. Meeting the protein requirements of animals through the correct formulation of diets is one way to avoid that excesses of urea are excreted into the environment; that is an important measure to reduce the environmental impact of production systems and prevent excessive nutrients in the diet. In addition, the excretion of urea represents high biological costs and use of energy to maintain body nitrogen concentrations at levels that do not affect the animals. The conversion of ammonia into urea demands 12 $\mathrm{kcal} / \mathrm{g}$ of nitrogen (Van Soest, 1994).

It was observed statistical difference $(\mathrm{p}<0.05)$ in the process selection of nitrogen intake among the diets with different protein sources and the animals fed the diet containing aerial part of the cassava hay ingested greater $(p<0.05)$ amount of nitrogen compared to other diets (Table 3). However, it is important to note that part of the nitrogen ingested by animals this diet was not seized upon by the animal due to the high content of ADIP that contained this diet as compared mainly to the other diets (Table 1).

Losses of nitrogen through the urinary tract are related to the rumen degradable protein content in the diet; in addition, the higher the consumption of this nutrient, the greater the amount of ammonia produced, which could exceed the use by ruminal microorganisms, hence resulting in increased synthesis of urea in the liver and higher excretion via urine. Therefore, it was observed that diets containing cottonseed meal presented $(\mathrm{p}<0.05)$ higher nitrogen loss in urine in relation to other diets (Table 3).

Regardless of the protein source, the nitrogen excretion in urine observed in this study was on average $6.6 \mathrm{~g} / \mathrm{d}$. Likewise, Felisberto et al. (2011) has found an average of $6.5 \mathrm{~g} / \mathrm{d}$ when assessing the use of soybean meal, toasted soybeans, corn gluten meal and cottonseed meal as protein sources in diets formulated to non-lactating goats.

We observed a higher $(\mathrm{p}<0.05)$ nitrogen content in feces 
Table 3. Nitrogen balance in lactating goats fed with diets containing different protein sources in the concentrate

\begin{tabular}{|c|c|c|c|c|c|c|}
\hline \multirow{2}{*}{ Item } & \multicolumn{4}{|c|}{ Protein sources in the diet } & \multirow{2}{*}{ SEM } & \multirow{2}{*}{ p-value } \\
\hline & Soybean meal & Cottonseed meal & Cassava hay & Leucaena hay & & \\
\hline Ingested nitrogen $(\mathrm{g} / \mathrm{d})$ & 31.9 & 30.4 & 34.0 & 31.9 & 1.25 & 0.004 \\
\hline Nitrogen urine $(\mathrm{g} / \mathrm{d})$ & 6.1 & 11.1 & 4.3 & 5.1 & 0.72 & $<0.001$ \\
\hline Nitrogen feces (g/d) & 13.3 & 13.5 & 17.5 & 16.2 & 0.94 & 0.042 \\
\hline Nitrogen milk (g/d) & 6.9 & 6.5 & 6.0 & 6.6 & 0.33 & 0.187 \\
\hline Digested nitrogen (g/d) & 18.6 & 16.9 & 16.5 & 15.6 & 0.82 & 0.352 \\
\hline Digested nitrogen (g/kg IN) & 582.5 & 558.8 & 490.4 & 490.30 & 2.01 & 0.175 \\
\hline Retained nitrogen (g/d) & 5.6 & -0.7 & 6.2 & 4.1 & 0.91 & 0.029 \\
\hline Retained nitrogen (g/kg IN) & 166.7 & -22.1 & 178.8 & 125.0 & 2.60 & 0.006 \\
\hline \multirow[t]{3}{*}{ Retained nitrogen $(\mathrm{g} / \mathrm{kg} \mathrm{DN})$} & 285.5 & -57.4 & 363.4 & 240.7 & 5.04 & 0.003 \\
\hline & \multicolumn{6}{|c|}{ Analyses of contrasts } \\
\hline & $\mathrm{SM}_{\mathrm{vs}} \mathrm{CM}^{1}$ & $\mathrm{SM}$ vs $\mathrm{CH}^{2}$ & $\mathrm{SM}$ vs $\mathrm{LH}^{3}$ & $\mathrm{CM}$ vs $\mathrm{CH}^{4}$ & $\mathrm{CM}$ vs $\mathrm{LH}^{5}$ & $\mathrm{CH}$ vs $\mathrm{LH}^{6}$ \\
\hline Ingested nitrogen $(\mathrm{g} / \mathrm{d})$ & 0.037 & 0.009 & 0.945 & 0.001 & 0.041 & 0.008 \\
\hline Nitrogen urine (g/d) & $<0.001$ & 0.0308 & 0.1621 & $<0.001$ & $<0.001$ & 0.357 \\
\hline Nitrogen feces (g/d) & 0.8853 & 0.017 & 0.070 & 0.022 & 0.089 & 0.407 \\
\hline Retained nitrogen (g/d) & 0.012 & 0.757 & 0.410 & 0.008 & 0.037 & 0.272 \\
\hline Retained nitrogen (g/kg IN) & 0.003 & 0.814 & 0.421 & 0.002 & 0.012 & 0.304 \\
\hline Retained nitrogen (g/kg DN) & 0.003 & 0.414 & 0.635 & 0.001 & 0.007 & 0.207 \\
\hline
\end{tabular}

IN, nitrogen intake; DN, nitrogen digested; SEM, standard error of mean.

${ }^{1}$ Probability of contrast between soybean meal (SM) and cottonseed meal (CM).

${ }^{2}$ Probability of contrast between soybean meal (SM) and aerial part of cassava hay $(\mathrm{CH})$

${ }^{3}$ Probability of contrast between soybean meal (SM) and leucaena hay (LH).

${ }^{4}$ Probability of contrast between cottonseed meal $(\mathrm{CM})$ and aerial part of cassava hay $(\mathrm{CH})$.

${ }^{5}$ Probability of contrast between cottonseed meal (CM) and leucaena hay (LH).

${ }^{6}$ Probability of contrast between aerial part of cassava hay $(\mathrm{CH})$ and leucaena hay $(\mathrm{LH})$.

for the diet with aerial part of the cassava hay, principally when compared with soybean meal and cottonseed meal. Possibly, this fact was evidenced due to higher consumption of nitrogen that was provided by the diet containing aerial part of the cassava hay (Table 3). Moreover, it is important infer that the result obtained for this variable, confirms the above statement, of that part of the nitrogen ingested by animals fed the diet containing aerial part of the cassava hay was not tapped.

The insoluble protein levels in acid detergent were $212.4 ; 221.1 ; 246.6$ and $226.1 \mathrm{~g} / \mathrm{kg}$ of $\mathrm{DM}$ for the respective diets with soybean meal, cottonseed meal, aerial part of cassava hay and leucaena hay. Yet, the greatest loss of nitrogen in the feces of animals fed with aerial part of the cassava hay was probably due to the higher insoluble protein levels in acid detergent contained in this diet (Table 1). The ADIP is the protein that is linked to the fiber, especially the lignin, which is not used in any compartment of the gastrointestinal tract and is therefore eliminated in feces.

The excretions of nitrogen in milk were not significantly affected $(p>0.05)$ by the diets with different protein sources and presented an average of $6.5 \mathrm{~g} / \mathrm{d}$ among diets (Table 3). The values obtained in this experiment were lower than those reported by Fonseca et al. (2008) for lactating goats, which registered averages of $12.2 ; 12.5$;
12.6 and $14.3 \mathrm{~g} / \mathrm{d}$ for CP levels $(115.0 ; 135.0 ; 155.5$ and $175.5 \mathrm{~g} / \mathrm{kg}$ of CP in DM). The goats analyzed in this study showed an average consumption of $32.0 \mathrm{~g}$ nitrogen/day, whereas the animals analyzed by the above mentioned authors submitted an average value of $42.8 \mathrm{~g} / \mathrm{d}$ probably, this difference explains the lower mean observed.

Regarding the retained nitrogen $(\mathrm{g} / \mathrm{d}, \mathrm{g} / \mathrm{kg}$ of ingested and $\mathrm{g} / \mathrm{kg}$ of digested), it was found difference $(\mathrm{p}<0.05)$ among the experimental diets (Table 3 ). The use of diets with cottonseed meal, as a source of protein, resulted in negative nitrogen balance. Possibly the higher concentration of rumen degradable protein (Table 1) associated with high losses of nitrogen in the urine of the animals explains the absence of nitrogen retention by the animals fed this diet. Moreover this result indicates that the intake of nitrogen from animals fed on this diet was not sufficient to meet the requirements for maintenance and synthesis of tissues and could also lead to mobilization of body reserves, which, in the long term, could influence the estrus period and the intervals between pregnancies.

The excretions of allantoin in urine were not affected ( $p>0.05$ ) by diets with different sources of protein and showed an excretions average of $8.07 \mathrm{mmol} / \mathrm{d}$ (Table 4). By researching the effects of diet on the excretion of allantoin in the urine of lactating goats, Fonseca et al. (2006) have obtained allantoin excretions ranging from 12.9 to 16.9 
mmol/d, whereas Argôlo et al. (2010) have reported an average of $10.6 \mathrm{mmol} / \mathrm{d}$. It is important presume that the goats analyzed in this study were in middle lactation stage, whereas those analyzed in studies by the above mentioned authors were in early lactation stage. Given the interpretation of these results, it is assumed that the urinary excretions of allantoin in lactating goats are not constant in all physiological stages.

The allantoin excreted in urine has represented on average $586 \mathrm{~g} / \mathrm{kg}$ of the total urinary purine derivatives, and that average was close to the values found by the above mentioned authors.

The secretion of milk allantoin $(0.34 \mathrm{mmol} / \mathrm{d})$ was not affected $(\mathrm{p}>0.05)$ by the protein sources used in the diets (Table 4). Argôlo et al. (2010) have found an average of $0.34 \mathrm{mmol} / \mathrm{d}$ for the secretion of milk allantoin. Milk production is usually the major factor determining the concentration and amount of allantoin secreted in milk; thus, the same response observed between the experiments may be related to the similarity in milk production (1.77 vs 1.82 $\mathrm{kg} / \mathrm{d}$ ).
The secretion of allantoin in milk was accounted for 26 $\mathrm{g} / \mathrm{kg}$ of the TP derivatives excreted. This demonstrates that, despite the secretion of allantoin in milk is a non-renal route, it represents a significant fraction that should be therefore taken into account in estimating the absorption of purines, otherwise, it would be underestimated in lactating goats.

According to Yu et al. (2002), the excretion of uric acid, xanthine and hypoxanthine may be affected by sources of nitrogenous compounds and energy. This affirmation is consistent with the results found in this study, because it was no statistical difference $(\mathrm{p}<0.05)$ among the protein sources for the excretion of uric acid, xanthine, and hypoxanthine in the urine (Table 4). The diet containing leucaena hay showed higher means for these variables, when compared with soybean meal and cottonseed meal (Table 4).

The high enzymatic activity of xanthine oxidase in the blood and tissues of bovine animals converts xanthine and hypoxanthine into uric acid before excretion; thus, the determination of this metabolite in the urine of this species is not necessary. However, several studies involving goats

Table 4. Synthesis of microbial protein and microbial efficiency in lactating goats fed with diets containing different protein sources in the concentrate

\begin{tabular}{|c|c|c|c|c|c|c|}
\hline \multirow{2}{*}{ Item } & \multicolumn{4}{|c|}{ Protein sources in the diet } & \multirow{2}{*}{ SEM } & \multirow{2}{*}{$\mathrm{p}$-value } \\
\hline & Soybean meal & Cottonseed meal & Cassava hay & Leucaena hay & & \\
\hline \multicolumn{7}{|l|}{ Purine derivatives $(\mathrm{mmol} / \mathrm{d})$} \\
\hline Allantoin in urine & 7.2 & 8.8 & 7.9 & 8.4 & 0.52 & 0.284 \\
\hline Allantoin in milk & 0.36 & 0.36 & 0.32 & 0.33 & 0.02 & 0.529 \\
\hline Uric acid & 1.6 & 2.4 & 2.4 & 3.7 & 0.27 & 0.025 \\
\hline $\mathrm{XH}$ & 2.2 & 2.5 & 3.0 & 3.6 & 0.22 & 0.015 \\
\hline Total absorbed & 11.3 & 14.0 & 13.6 & 16.0 & 0.98 & 0.022 \\
\hline \multicolumn{7}{|l|}{ Microbial purines (mmol/d) } \\
\hline Purines & 14.9 & 18.5 & 17.9 & 21.1 & 0.74 & 0.022 \\
\hline \multicolumn{7}{|l|}{ Microbial production $(\mathrm{g} / \mathrm{d})$} \\
\hline Microbial nitrogen & 8.2 & 10.2 & 9.9 & 11.6 & 0.54 & 0.022 \\
\hline Microbial CP & 51.4 & 63.6 & 61.8 & 72.8 & 3.38 & 0.022 \\
\hline \multirow{3}{*}{$\begin{array}{c}\text { Microbial efficiency } \\
\text { (g CP/kg TDN) }\end{array}$} & 52.4 & 68.2 & 62.0 & 77.4 & 4.14 & 0.038 \\
\hline & \multicolumn{6}{|c|}{ Analyses of contrasts } \\
\hline & $\mathrm{SM}_{\mathrm{Vs}} \mathrm{CM}^{1}$ & $\mathrm{SM}_{\text {vs } \mathrm{CH}^{2}}$ & $\mathrm{SM}_{\mathrm{vs} \mathrm{LH}^{3}}$ & $\mathrm{CM}_{\text {vs }} \mathrm{CH}^{4}$ & $\mathrm{CM}_{\text {vs } \mathrm{LH}^{5}}$ & $\mathrm{CH}$ vs $\mathrm{LH}^{6}$ \\
\hline $\mathrm{XH}(\mathrm{mmol} / \mathrm{d})$ & 0.374 & 0.065 & 0.004 & 0.130 & 0.011 & 0.110 \\
\hline Uric acid (mmol/d) & 0.168 & 0.142 & 0.005 & 0.905 & 0.031 & 0.036 \\
\hline Total absorbed (mmol/d) & 0.041 & 0.069 & 0.004 & 0.711 & 0.099 & 0.058 \\
\hline Purines (mmol/d) & 0.041 & 0.069 & 0.004 & 0.709 & 0.099 & 0.058 \\
\hline Microbial nitrogen $(\mathrm{g} / \mathrm{d})$ & 0.040 & 0.069 & 0.004 & 0.708 & 0.099 & 0.058 \\
\hline Microbial CP (g/d) & 0.041 & 0.069 & 0.004 & 0.711 & 0.099 & 0.058 \\
\hline Microbial efficiency & 0.054 & 0.213 & 0.007 & 0.404 & 0.235 & 0.060 \\
\hline
\end{tabular}

XH, Xanthine and hypoxanthine; CP, crude protein; TDN, total digestible nutrients; SEM, standard error of mean.

${ }^{1}$ Probability of contrast between soybean meal (SM) and cottonseed meal (CM).

${ }^{2}$ Probability of contrast between soybean meal (SM) and aerial part of cassava hay $(\mathrm{CH})$.

${ }^{3}$ Probability of contrast between soybean meal (SM) and leucaena hay (LH).

${ }^{4}$ Probability of contrast between cottonseed meal $(\mathrm{CM})$ and aerial part of cassava hay $(\mathrm{CH})$.

${ }^{5}$ Probability of contrast between cottonseed meal (CM) and leucaena hay (LH).

${ }^{6}$ Probability of contrast between aerial part of cassava hay $(\mathrm{CH})$ and leucaena hay $(\mathrm{LH})$. 
have demonstrated the low or zero activity of the enzyme xanthine oxidase, thus requiring that the TP derivatives are quantified, but not underestimated. In this experiment, the excretions of xanthine and hypoxanthine was in average of $204.0 \mathrm{~g} / \mathrm{kg}$ of the total excreted purine derivatives and a very significant percentage was considered for the quantification of TP and absorbed purines (Table 4).

Microbial protein production followed the same pattern observed for the excretion of purine derivatives and total absorbed purines and showed differences $(p<0.05)$ the means of diets containing soybean meal and leucaena hay and the difference was greater in the case of that containing leucaena hay $(41.5 \%$ higher) (Table 4$)$. This behavior indicates a high correlation between the excretion of purine derivatives and nitrogen flow in the duodenum.

The estimates of microbial nitrogen synthesis observed in this study $(8.23 ; 10.18 ; 11.65$ and $9.89 \mathrm{~g} / \mathrm{d})$ for diets including soybean meal, cottonseed meal, aerial part of the cassava hay and leucaena hay were lower than those reported by Fonseca et al. (2006), who reported values ranging from 13.3 to $17.3 \mathrm{~g} / \mathrm{d}$ for lactating goats fed diets with protein. Yet, according to Argôlo et al. (2010), who worked in the replacement of maize by mesquite pod meal in the diet of lactating goats, these values were close to those of the microbial nitrogen flow (13.74 to $9.86 \mathrm{~g} / \mathrm{d}$ ). These authors have observed that the addition of mesquite pod meal in the concentrate negatively influenced the flow of microbial nitrogen as well as the efficiency of microbial protein synthesis. These authors have associated related this fact to the source of carbohydrates; thus, diets with high content of neutral detergent soluble fiber in the form of pectin may limit the supply of metabolizable protein of microbial origin on the small intestine and require supplemental protein sources of low ruminal degradability.

The diet containing leucaena hay showed concentrations of ruminal degradable protein higher those observed in the diet with soybean meal (Table 1). Thus, the increased flow of microbial nitrogen provided by the association of the mesquite pod meal with leucaena hay may be associated with the compatibility of the degradation of carbohydrates contained in mesquite pod meal with nitrogen compounds of leucaena hay.

Results of microbial efficiency (in $\mathrm{g} \mathrm{CP} / \mathrm{kg}$ TDN) observed in this experiment were significantly affected $(\mathrm{p}<0.05)$ by the combination of mesquite pod meal with protein sources and ranged from 52.3 to $77.4 \mathrm{~g} \mathrm{CP} / \mathrm{kg}$ TDN. The microbial efficiency was observed to me more efficient in the diet containing leucaena hay than in that containing soybean meal.

In general, the leucaena hay brought benefits to production and improved the efficiency of microbial synthesis. The average values observed for $64.98 \mathrm{~g}$ of MCP per pound of TDN (MCP/kg of TDN) were far below those reported by the NRC (2001) for bovine animals (130 g $\mathrm{MCP} / \mathrm{kg}$ of TDN).

\section{CONCLUSIONS}

The use of diets with cottonseed meal as protein source in the concentrate in feeding of lactating goats provides greater nitrogen excretion in urine and negative nitrogen balance, while the concentrate with leucaena hay as a source of protein, provides greater ruminal microbial protein synthesis.

\section{ACKNOWLEDGMENTS}

The work was supported by the Research Foundation of the State of Bahia-Brazil.

\section{REFERENCES}

Argolo, L. S., M. L. A. Pereira, J. C. T. Dias, J. F. Cruz, A. J. Del Rei, and C. A. S. Oliveira. 2010. Mesquit pod meal in diets of lactating goats: ruminal parameters and microbial efficiency synthesis. R. Bras. Zootec. 39:541-548.

Belenguer, A., D. Yanez, J. Balcells, N. H. Ozdemir Baber, and M. Gonzalez Ronquillo. 2002. Urinary excretion of purine derivatives and prediction of rumen microbial outflow in goats. Livest. Prod. Sci. 77: 127-135.

Carvalho, G. G. P., R. Garcia, A. J. V. Pires, R. R. Silva, M. L. A. Pereira, P. T. Viana, A. B. Santos, and T. C. J. Pereira. 2010. Nitrogen balance, urea concentrations and microbial protein synthesis in goats fed diets containing sugar cane treated with calcium oxide. R. Bras. Zootec. 39: 2253-2261.

Casali, A. O., E. Detmann, Valadares Filho, J. C. Pereira, L. T. Henriques, S. G. Freitas, and M. F. Paulino. 2008. Influence of incubation time and particles size on indigestible compounds contents in cattle feeds and feces obtained by in situ procedures. R. Bras. Zootec. 37:335-342.

Chen, X. B. and M. J. Gomes. 1992. Estimation of Microbial Protein Supply to Sheep and Cattle Based on Urinary Excretion of Purine Derivatives - An Overview of the Technical Details. International Feed Resources Unit, Rowett Research Institute, Bucksburn, Aberdeen, AB2 9SB, UK. (Occasional publication). p.21.

Felisberto, N. R. O., M. T. Rodrigues, M. A. D. Bomfim, R. S. Matos, A. G. P. C. Cordeiro, and M. M. C. Silva. 2011. Effects of different sources of protein on digestive characteristics, microbial efficiency, and nutrient flow in dairy goats. R. Bras. Zootec. 40:2228-2234.

Fonseca, C. E. M., R. F. D. Valadares, S. C. Valadares Filho, M. I. Leão, and M. I. Marcondes. 2008. Digestion of the nutrients and nitrogen compounds balance in goats fed with different levels of protein. Arq. Braz. Med. Vet. Zootec. 60:192-200.

Fonseca, C. E. M., R. F. D. Valadares, S. C. Valadares Filho, M. I. Leão, P. R. Cecon, M. T. Rodrigues, D. S. Pina, M. I. Marcondes, M. L. Paixão, and A. M. Araújo. 2006. Microbial protein synthesis in lactating goats fed diets with increasing levels of dietary protein. R. Bras. Zootec. 35(Suppl.):1169- 
1177.

Hall, M. B. 2003. Challenges with non-fiber carbohydrate methods. J. Anim. Sci. 81:3226-3232.

Ítavo, L. C. V., S. C. Valadares Filho, F. F. Silva, R. F. D. Valadares, M. F. Paulino, C. C. B. F. Ítavo, and E. H. B. K. Moraes. 2002. Comparison of markers and collection methodology for fecal production and digesta flow estimates in bovine. R. Bras. Zootec. 31:1833-1839.

Jonker, J. S., R. A. Kohn, and R. A. Erdman. 1999. Milk urea nitrogen target concentrations for lactating dairy cows fed according to national research council recommendations. J. Dairy Sci. 82:1261-1273.

Licitra, G., T. M. Hernandez, and P. J. Van Soest. 1996. Standardization of procedures for nitrogen fracionation of ruminant feeds. Anim. Feed Sci. Technol. 57:347-358.

Mendes, C. Q., R. H. R. Fernandes, I. Susin, A. V. Pires, and R. S. Gentil. 2010. Partial replacement of soybean meal by urea or starea feeding of lactating goats. R. Bras. Zootec. 39:18181824.

Mertens, D. R. 2002. Gravimetric determination of amylasetreated neutral detergent fiber in feeds with refluxing in beakers or crucibles: Collaborative study. J. AOAC Int. 85: 1217-1240

Murta, R. M., M. A. Chaves, A. J. V. Pires, C. M. Veloso, F. F. Silva, A. L. Rocha Neto, and A. Eustáquio Filho. 2011. Performance and nutrients apparent digestibility in sheep fed diets containing sugar cane bagasse treated with calcium oxide. R. Bras. Zootec. 40:1325-1332.

Neiva Júnior, A. P., E. H. C. B. Van Cleef, and R. M. P. Pardo 2007. Agroindustrial byproducts of biodiesel in ruminant feed. In: II Congress of the Brazilian Network Technology and Biodiesel Production, Brasília, DF. Proceedings Brasília, DF. RBTPB:1-6.

NRC (National Research Council). 2001. Nutrient Requirements of Dairy Cattle. 7 ed. National Academy Press, Washington, DC, USA. p. 381.
NRC (National Research Council). 2007. Nutrient Requirements of Small Ruminants. 1 ed. National Academy Press, Washington, DC, USA. p. 362.

Nunes Irmão, J., M. P. Figueiredo, L. G. R. Pereira, J. Q. Ferreira, and J. L. Rech. 2008. Chemical composition of cassava stem and foliage hay in different harvesting ages. Rev. Bras. Saude Prod. An. 9:158-169.

Oliveira, C. A. S. 2009. Mesquite pod meal in diets for lactating goats. State University of Southwest Bahia. p. 48.

Pessoa, R. A. S., M. I. Leão, M. A. Ferreira, S. C. Valadares Filho, R. F. D. Valadares, and A. C. Queiroz. 2009. Nitrogenous compounds balance and microbial protein production in crossbred heifers fed forage cactus, sugar cane bagasse and urea associated to different supplements. R. Bras. Zootec. 38:941-947.

Segundo, L. F. F., M. N. B. A. Araripe, and J.B. Lopes. 2006. Substitution of the Soybean Meal for Leucena Hay in the Feeding of Tilapia Fingerlings. Rev. Cient. Prod. Anim. 8:2834.

Silva, D. J. and A. C. Queiroz. 2002. Food analysis: Chemical and biological methods. Viçosa: Federal University of Viçosa.

Tas, B. M. and A. Susenbeth. 2007. Urinary purine derivates excretion as an indicator of in vivo microbial $\mathrm{N}$ flow in cattle: A review. Livest. Sci. 111:181-192.

Valadares Filho, S. C. and D. S. Pina. 2006. Rumen fermentationl. Jaboticabal: Funep, pp. $151-182$.

Van Soest, P. J. 1994. Nutritional Ecology of the Ruminant. Cornell University Press, Ithaca, NY, USA. p. 476.

Vasconcelos, A. M., M. I. Leão, S. C. Valadares Filho, R. F. D. Valadares, M. Dias, and D. A. E. F. Morais. 2010. Ruminal parameters, nitrogen compound balance and microbial production in dairy cows fed soybeans and their by-products. R. Bras. Zootec. 39:425-433.

Yu, P., A. R. Egan, L. Boon-Ek, and B. J. Leury. 2002. Purine derivative excretion and ruminal microbial yield in growing lambs fed raw and dry roasted legume seeds as protein supplements. Anim. Feed Sci. Technol. 95:33-48. 